\title{
Article
}

\section{Legitimasi Kepala Desa Terpilih Tahun 2016 di Desa Air Liki Baru Kecamatan Tabir Barat Kabupaten Merangin}

\author{
Siti Maryam J ${ }^{1 *}$, Rano Saputra ${ }^{2}$
}

This article is an open access article distributed under the terms and conditions of the Creative Commons Attribution-ShareAlike 4.0 International (CC BY SA ) License (https://creativecommo ns.org/licenses/bysa/4.0/).

\section{Jurnal Politik dan} Pemerintahan Daerah ISSN 2686-2271

Fakultas Ilmu Sosial dan Ilmu Politik, Universitas Muara Bungo Jl. Diponegoro No. 27, Muara Bungo-Jambi, (0747) 323310

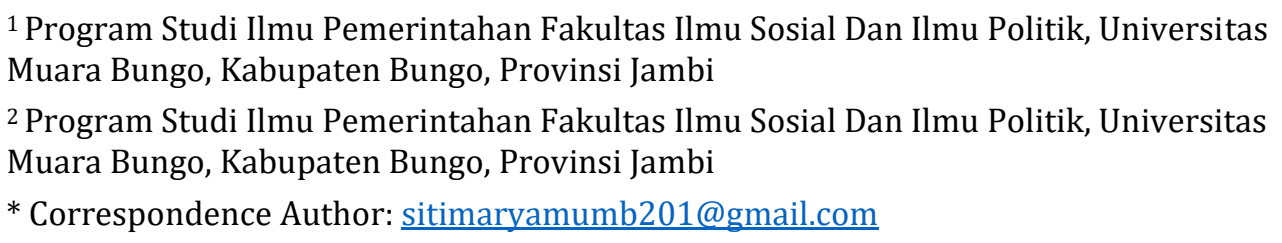

Abstract: General post-pilkades problems often occur in Indonesia, post-pilkades problems in the new air liki village, the background of this research is the form of conflict that arose after the 2016 village head election and the efforts made by the village head in resolving internal conflicts in the village of Air Liki Baru, the sub-district of West Curtain, Merangin and the efforts made by the village head in resolving the conflict in the village of Air Liki Baru, Tabit Barat District, Merangin Regency, this study aims to determine the resolution of the post-pilkades conflict in the Air Liki Baru village. The method used in this study is a qualitative descriptive approach where this researcher describes the problems that exist there, data collection techniques, observation, interviews, and documentation, informant selection techniques using purposive sampling, analysis of results and interviews and the data is divided into one by one according to the legislative elements and the refined data is classified according to the category based on From the results of interviews and observations, it can be concluded that the forms of conflict that emerged after the 2016 Pilkades were personal conflicts, refusal to accept village development programs, not wanting to participate in mutual cooperation, not wanting to participate in village development meetings and political conflicts, village regulations violations, money politics and nepotism. there is also the impact that occurs on village development, namely the inhibition of village development in the field of village road infrastructure. Meanwhile, the effort to resolve it is through conciliation, which is to bring together the wishes of the disputing parties in order to achieve a mutual agreement and compromise where the parties involved reduce their demands in order to achieve a resolution of the conflicts that occur.

Keywords: the legitimacy of the elected village head, pilkades

Abstrak: Permasalahan umum pasca pilkades memang sering terjadi di Indonesia, permasalahan pasca pilkades desa air liki baru, latar belakang penilitian ini yaitu bentuk konfilk yang muncul pasca pilkades tahun 2016 dan upaya yang dilakaukan kades dalam penyelesaiaan konflik internal didesa air liki baru kecamatan tabir barat kabupaten merangin dan upaya yang dilakukan kades dalam menyelesaikan konflik didesa air liki baru kecamatan tabit barat kabupaten merangin, penelitian ini bertujuan untuk mengetahui penyelesaiaan konflik pasca pilkades desa air liki baru.Metode yang dilakukan dalam penelitian ini dengan pendekatan diskriptif kualitatif dimana peneliti ini menggambarkan permasalahan yang ada disana, teknik pengumpulan data, ovservasi, wawancara, dan dokumentasi, teknik pemilihan informan yang menggunakan purposive sampling, analisis hasil dan wawancara dan data dibagi menjadi satu persatu sesuai dengan elemen leguistik dan data disempurnakan digolongkan sesuia dengan katogorinya berdasarkan hasil wawancara serta 
pengamatan dapat disimpulkan bentuk-bentuk konflik yang muncul pasca pilkades tahun 2016 yaitu konfilik pertentangan pribadi tidak mau menerima program-program pembagunan desa tidak mau ikut gotong royong, tidak mau ikut muslembangdes dan pertentangan politik, pelanggaran perdes, politik uang dan nepotisme ada pun dampak yang terjadi terhadap pembaunan desa yaitu terhambatnya pembangunan desa di bidang insprastrukktur jalan desa. Sedangkan upaya penyelesaiaanya melalui concialiation yaitu mempertemukan keinginan-keinginan dari pihak-pihak yang berselisih demi tercapainya suatu persetujuan bersama dan compromise dimana pihak-pihak yang terlibat mengurangi tuntutanya agar tercapainya suatu penyelesaiaan konflik yang terjadi.

Kata kunci: legitimasi kepala desa terpilih, pilkades

\section{Pendahuluan}

Proses demokrasi dipelintir begitu rupa, sehinga dalam setiap pemilu akan dapat dengan mudah memprediksi siapa yang akan memenang. Tapi desakan dari dalam maupun dari luar membuat gerakan reformasi berkembang dengan akhir nya Indonesia harus belajar lagi untuk menerapkan demokrasi dalam jalurnya yang benar. Indonesia merupakan negara majemuk yang memiliki berbagai macam suku, budaya, serta agama dan oleh sebab itu tidak dipungkiri bahwa pandangan politik masing-masing individupun akan berbeda (Hikmawan, 2017).

Persaingan politik memenangkan kopetinsi pemilu sesuai dengan aturan dan ketentuan yang berlaku, dimana partai politik perlu monitor dan mengevaluasi setiap prinsip dan setiap pemenangan dari suatu pemain merupakan kekalahan dari pihak lain,yang paling penting dalam system demokrasi yang ideal adalah yang mana kontestan dapat merebut hati masyarakat melalui program kerja yang ditawarkan. Masyarakat berada pada dalam posisisi yang mana menentukan siapa yang menang dan siapa yang kalah. Dengan demikian, kemengan kontestan merupakan fungsikedekatan dan keberpihakan pada bangsa dan Negara. Dalam persaingan antar partai politik, harus dilakukan manajemen yang baik dalam partai agar demokrasi dalam suatu negara dapat berkualitas baik.(Syamsuadi et al., 2020)

Dengan ada nya persaingan masisng-masing pihak akan berlomba untuk menjadi yang terbaik. Hal ini mendorong orang yang berkopetensi terus memutar otak supaya sealu up-to-date dalam kondisi masyarakat yang membuat pemecahan yang berhasil dimasa lampau dan menjadi cepat usam. Selain itu masyarakatpun tidak hentinya memberikan ide dan gagasan mengenai permasalahan tertentu. Pada suatu pemilihan kepala desa (PILKADES). Perlu diketahui salah satu persaiangan politik tidak lah asing dalam hal ini apalagi jika kita melihat persaingan pada saat PILKADES.

Pada pelaksanaan pemilihan Kepala Desa atau yang lebih sering dikenal dengan "PILKADES" merupakan suatu sistem yang diterapkan sebagai bentuk aturan demokrasi dalam tataran pemerintahan. Secara tidak langsung dalam pemilihan kepala desa(Pilkades), masyarakat ikut adil dalam mensukseskan dan menjadi bagian terpenting dalam suatu demokrasi terpimpin. Selama ini dalam tataran pemerintah yang paling bawah dalam pemilihan kepala desa (PILKADES) menjadi perbincangan yang menarik untuk diangkat sebagai fenomena yang menarik. Hal ini terjadi karena pemilihan kepala desa (PILKADES) merupakanrefleksi bagaimana demokrasi itu mencoba untuk diimplementasikan.

Disisi lain dalam PILKADES merupakan sarana sirkulasi elit dan transfer kekuasaan di tingkat lokal. Dua momen tersebut akan memperoleh porsi berbeda yang menguras pikiran dan emosi masyarakat. Pilkades dan Pilkada tidak hanya 
bersinggungan dengan perebutan untuk memperolehkekuasaan, melainkan sudah berbicara tentang kelompok elit politik local (Dhuroriudin, 2005).

Pemerintah yang saat ini sedang mengengcar-gencarnya membangun dari bawah terutama dari desa sampai ke kota sesuai dengan moto pemerintah yaitu " membangun dari desa" dan juga menjadi melunjaknya penyebab masyrakat untuk berlomba-lomba menjadi kepala desa apalagi ditambah dengan angaran 1 milyar yang diberikan pemerintah kepada desa membuat minat masyarakat menjadi kepala desa meningkat. (http://digilib.uinsby.ac.id/15436/4/bab\%201.pdf)

Pada suatu pilkades Desa air liki baru, Kec tabir barat,Kabupaten Merangin terjadi juga melonjak minat masyarakat untuk mencalonkan diri untuk menjadi kepala desa. Dimana dalam hal ini dibuktikan dengan adanya 4 calon kandidat yang maju pada pilkades tahun 2016. Ke 4 calon kandidat yang bakal mencalon kan diri yaitu,bapak erwan dinata,bapak indara, bapak husni syadri dan bapak martunis.Di lihat dari hasil pemilihan kepala desa(pilkades), 2016 desa air liki baru bahwa bapak husni syadri lah yang lebih ungul memperoleh suaranya dari pada kadidat yang lain, sehingga dengan mutlak bapak husni syadri menang dalampemilihan kepala desa(PILKADES) desa air liki baru tahun 2016 (Sodikin, 2017).

Pasca kemenanganpemilihan kepala deasa (PILKADES),desa air liki baru tahun 2016 tentu banyak kandidat yang kalah dan para pendukung nya tidak suka dengan kepemimpinan kades terpilih (Sodikin, 2017). Pada saat akan dilaksanakan pelantikan kades terpilih dan aparat desa yang akan dilantik terjadilah suatu konflik, yang mana tempat dan lokasi pada saat pelantikan itu masih ada hak dan wewenang dari pihak pendukung calon kades yang kalah dan hubungan antara kades terpilih dengan temses kades yang kalah itu di sebut dengan (ninek mamak rumah) oleh kades terpilih.

Maka dari itu pihak pendukung paslon kades yang kalah menghalangi dan menggalkan pelatikan yang akan di laksanakan oleh panitia pelaksana dengan cara yang akan di lakukan nya oleh pendukung paslon kades yang kalah yaitu memberi 2 pilihan kepada kades terpilih yaitu, (1) kepala desa terpilih di suruh mengantikan aparat yang akan dilantik dan akan diganti dengan orang-orang dari pihak pendukung paslon kades yang kalah. (2) jika tidak mau mengikuti pilihan yang ke 1 maka dari pihak pendukung paslon yang kalah akan membuat keributan secara terus menerus dan selalu menghalang visi dan misi yang akan di wujudkan oleh kepala desa terpilih.

Dengan pilihan yang di berikan kepada kepala desa terpilih, maka kepala desa terpilih mengambil kesimpulan bahwa kepala desa terpilih tidak mau mengikuti apa kemauan dari pendukung paslon kades yang kalahdan kepala desa terpilih sanggup meneriman atau mengadapi apapun yang akan terjadi demi kekompakan antara kades terpilih dengan pendukungnya.

Pada saat itu pendukung paslon kades yang kalah mendengar ucapan dari kepala desa terpilih sangatmenantang bagi beliau dengan wajah marah dan berteriak dengan suara yang keras pendukung paslon kades yang kalah itu melarang melaksanakan pelantikan di tanah atau di halaman rumah kepala desa terpilih karena pihak pendukung dari paslon kades yang kalah mempunyai hak untuk melarang dan merusak tenda yang berdiri di tempat pada saat pelantikan. Dengan suasana yang begitu memanas dan disertai emosi dari kedua pihak baik dari pendukung paslon kepala desa terpilih maupun dari pihak pendukung kades yang kalah sehingga hendak terjadi keributan/perkelahian di saat pelantikan. (Ketua Panitia Kades Desa Air Liki Baru, Wawancara, 9 Januari 2020)

Dengan melihat permasalahan terjadipanitia penyelenggara mengambil keputusan yaitu memindahkan lokasi pelantikan ke lokasi tahan atau halaman rumah milik masyrakat dari pihak pendukung kepala desa terpilih yang akan di 
lantik pada saat itu, sehingga pelantikan bisa berjalan dengan lancar sampai selesai. Pasca pelantikan konflik terus berlanjut ada salah satu pendukung paslon kades yang kalah masih tidak menerima kekalahan nya sehinga terjadi nya suatu konflik. Yang mana halya dari pihak pendukung paslon yang kalah tidak mau berpartisipasi atau bekerjasama dalam menjalankan program kerja yang sudah di bentuk oleh kepala desa terpilih seperti kegiatan gontoroyong dan juga tidak mau menerima program pembangunan desa, dan menghalangi suatu pembangunan proyek insfrasruktur jalan yang mana tidak diperbolehkan kepala desa terpilih membuat atau membangun dan memperbaiki jalan yang berada di sekitar tanah milik pihak pendukung paslon kades yang kalah.

Table. 1. Hasil Perhitungan Perolehan Suara Masing-Masing Calon Kepala Desa

\begin{tabular}{l|l} 
No & \multicolumn{1}{|c}{ Nama Calon } \\
1 & Erwan Dinata \\
2 & Indra Gunawan \\
3 & Husni Syadri \\
4 & Martunis
\end{tabular}

TOTAL

\author{
Perolehan Suara \\ 65 Suara \\ 74 Suara \\ 85 Suara \\ 71 Suara \\ 295 Suara sah
}

Sumber: Panitia pemilihan kepala desa, desa air liki baru kecamatan tabir barat kabupaten merangin tahun 2016.

Dari data hasil perhitungan suara diatas dapat dilihat bahwa bapak husni syadri yang lebih unggul memperoleh suara yang terbannyak dari kandidat calon pilkades yang lain, sehingga dengan mutlak bapak husni syadri dinyatakan menang dalam pemilihan kepala desa di desa air liki baru Kec tabir barat, Kabupaten merangin tahun 2016.

Sehingga membuat terhambatnya suata pembangunan infrastruktur jalan umum dan merugikan masyarakat yang mana halnya jalan tersebut tidak boleh di perbaiki sehingga masyarakat masih belum bisa menikmati meratanya pembangunan jalan masih melewati jalan berlobang, walaupun angaran jalan tersebut tetap di gunakan oleh kades terpilih untuk memperbaiki jalan yang tanahmilik keluarga kades terpilih. Maka dari itu konflik ini sangat berdampak buruk bagi masyrakat dengan terhambatnya suatu kemajuan perekonomian desa air liki baru (Tohirin, Wawancara, 20 Januari 2020).

Bagaimana pun bentuk konflik yang terjadi antara kepela desa terpilih dengan paslon kades yang kalah beserta pendukungnya, kepala desa terpilih tidakmau melaporkan kepada pihak pemerintah merangin. Kepala desa terpilih lebih memilih cara penyelesaian konflik yang terjadi dengan cara menyelesaikan secara adat karena hubungan antara kepala desa terpilih dengan pendukung paslon kades kalah mempunyai tuturan bahasa dusun air liki baru (ninek mamak rumah), atau yang biasa disebut orang yang mempunyai wewenang dan kekuasaan di dususun yang di tempati oleh kades terpilih.

Terdapat juga ada suatu konflik dan permasalahan yang terjadi pasca PILKADES tahun 2016. Antara elit politik lokal dengan masyarakat dan pendukung paslon kades yang kalah. Yaitu adanya saling kritik dan saling menuding satu sama lain, dan munculnya ada dugaan yang tidak baik dilakukan oleh pendukung paslon kepala desa yang kalah terhadap kepala desa terpilih, yang mana keluar isu kepala desa yang bernama husni syadri mengelabkan dana desa dan sampai isu tersebut di angkat atau di laporkan kepada pihak pemerintah Kabupaten Meraningin dengan melalui surat maupun mengunakan media sosial facebook. Sehingga turun lah dari pihak pemerintah kabupaten merangin untuk menggecek/memeriksa apa isu atau dugaan yang di lakukan terhadap kepala desaair liki baru yang bernama husni 
syadri, pihak pemerintah kabupaten merangin tidak menemukan atas apa isu atau permasalahan yang sesuai laporan oleh masyarakat pendukung palon kades yang kalah terhadap kepala desa husni syadri dalam pengelapan dana (http//id.m.wikepedia.org/wiki/penyelesaiaankonflik)

Dengan berbagai bentuk konflik yang terjadi pasca pilkades desa air liki baruyaitu dengan cara yang penyelesaiannya yang mana kepala desa terpilih merangkul semua masyarakat baik masyarakat yang pro maupun yang kontra dengan kades terpilih, adapun cara yang di lakukan yaitu mendekatkan diri dengan pendukung dan paslon kades yang kalah dengan cara ada salah satu proyek pembangunan jalan dan jembatan gantung kepala desa terpilih memberikan atau mempercayai pendukung dari paslon kades yang kalah sebagai kepala tukang dalam pelaksanaan proyek tersebut (Candra, Wawancara, 30 Januari 2020). Dan juga kades terpilih membuat suatu perkumpulan dan musyawarah desa yang di hadiri oleh seluruh lapisan masyarakat, ketua BPD dan tokoh adat yang selengarakan di kantor desa.

Yang mana isi musyawarah tersebut kepala desa terpilih mengajak paslon yang kalah dan pendukungnya untuk membantu dan berkerjasama baik di segi pertanian maupun di segi pembangunan insfasruktur jalan demi kemajuan desa air liki baru. Begini lah bentuk penyelesaian konflik yang terjadi pasca PILKADES desa air liki tahun 2016.

Berdasarkan uraian di atas peneliti tertarik untuk melakukan penelitian dengan mengajukan judul "LEGITIMASI KEPALA DESA TERPILIH HASIL PEMILIHAN PADA PILKADES TAHUN 2016. (Studi desa air liki baru, Kec tabir barat, Kupaten Merangin).

\section{Pembahasan}

\section{Bentuk konflik yang muncul pasca pilkades tahun 2016 di Desa air liki baru}

Konflik merupakan perbedaan atau pertantangan antara individu atau kelompok sosial yang terjadinkarena perbedaan kepentingan, serta adanya usaha memenuhi tujuan dengan jalan menantang pihak lawan disertai dengan ancaman atau kekerasan. Pasca pilkades desa air liki baru tahun 2016 terjadi namanya perselisihan atau di sebut konflik. Dalam hal ini konflik yang muncul akibat para kandidat calon kades yang kalah dan pendukungnya, dikarenakan belum bisa berbesar hati menerima kekalahannya. Sehingga mereka sengaja membuat kekacauan dan dengan slalu mengkritik dan tidak ikut berpartisispasi dalam kegiatan desa dan serta terang- terangan melangar peraturan desa.

Bentuk-bentuk konflik yang muncul pasca pilkades di Desa air liki baru antara lain:

1. Konflik atau pertantangan pribadi

yaitu konflik yang terjadi antara dua individu atau lebih karena perbedaan pandangan dan sebagainya. Tidak mau menerima program-program pembangunan desa dalam hal pertanian, UKM, dan pembangunan infrasruktur jalan desa yang di rancang dan di buat oleh kepala desa sama sekali tidak ada dukungandari pihak yang kalah dan lebih cendrung mendapat tantangan dari masyarakat angota pendukung kandidat yang kalah

konflik yang terjadi adalah Permasalah dan pertantangan program-program pembangunan desa tidak pernah lepas dari hasil pilkades 30 april 2016 yang memenangkan bapak husni syadri, sehinga dengan sengaja para kandidat dengan sengaja para kandidat yang kalah dan pendukungnya tidak mendukung dan menantang program-program desa yang hendak ia buat.

2. Program gontong royong

Program gotong royong merupakan kegiatan yang din laksanakan dengan membangun kerjasama yang baik antara individu dan kelompok dengan mewujudkan semangat persatuan dan kesatuan. Kebijakan gontong royong desa yang tiap 2 minggu sekali yang di laksanakan di hari jumat sama sekali tidak dinikuti oleh kandidat yang kalah dan para pendukungnya. 
Rendahnya keikut sertaan masyarakat terutama para kandidat yang kalah dan para pendukungnya dalam hal gotong royong desa, memberikan gambaran kepada kepala desa terpilih bahwa mereka semua belum bisa menerima kekalahan jagoan- jagoan kandidat mereka yang bertarung pada pilkades pada 30 april 2016 sehingga partisipasi masyarakat rendah dalam hal gotong royong. Tidak hadirnya masyarakat pendukung kandidat yang kalah padakegiatam program gotong royong di karenakan tidak terimanmya hasil kekalahan pada pilkades desa air liki baru yang mengakibatkan terjadinya suatu konflik karena tidak ikutsertaan para pendukung para kandidat di kegiatan progrom gotong royong mengakibatkan belum bisa terleksana dengan baikkarena terlaksananya suatu program itu harus di dukung oleh semua masyrakat dengan be kerjasama

3. Tidak mau ikut musrembangdes

a. Pada musrembangdes desa air liki baru adanya sebagian angota BPDdan masyrakat pendukung kandidat yang kalah dengan jelas memperlihatkan ketidak hadirannya pada rapat musrembangdes desa air liki baru. Adanya kesengajaan pribadi yang mengambarkan tentang bagaimana seseorang yang dulu ikut berpartisipasi dalam musrembangdes sekarang tidak lagi berpartisipasi dalam musrembangdes adalah sebuah wujud dan situasi pasca pilkades tahun 2016 yang mana masih tingginya emosi pada diri pribadi pendukung kandidat yang kalah terhadap hasil pilkades sehinga berdamfak sehinga berkurangnya perserta jumlah musrembangdes desa air liki baru.

b. Pada musrembangdes desa air liki baru yang tidak di hadiri olehkandidat dan pendukung yang kalah. Pada rapat musrembangdes desa air liki baru yang pada saat itu tidak di hadiri oleh salah satu kandidat paslon yang kalah beserta pendukungnya itu dinkarenakan tidak lah luput dari belum siapnya kandidat tersebut menerima hasil kekalahan pada pilkades sehingga mereka tidak mau menghadiri acara musrembangdes desa air liki baru, itu sangat berdampak tidak bagus untuk kemajuan desa tersebut jika ini konflik terurus-menus terjadi.

Konflik pilkades sangat berdampak buruk untuk pembangunan desa air liki baru karena salah satu kandidat dan para pendukungnya masih mementingkan egonya dari pada hadir hadir di acara musrembangdes tersebut, ini sangat di tidak bagus untuk kemajuan desa air liki baru karena musrembangdes itu adalah dimana semua setiap dusun harus mengajukan apa-apa saja pembangunan untuk dusun masin-masing dan itu harus di sepakati oleh seluruh masyarakat yang hadir di dalam acar musrembangdes desa air liki baru, jika konflik ini terus menurus terjadi akan betrdampak buruk terhadap kemajuan pembangunan desa air liki baru.

4. Dalam hal ke agamaan

a. Tidak mau sholat jumat berjamaah di dusun tempat kediaman kades terpilih ada 7 orang angota jamaah jumat memilih sholat jumat di masjid diluar dusun yang di tempat tinggal kades terpilih ini menunjukan konflik yang terjadi di desa air liki baru.

b. Dengan tidak mau salah satu kandidat pendukung kandidat sholat di masjid dimana dusun tempat tinggal kepala desa terpilih. konflik pasca pilkades berujung panjang samapai ke bidang keagaaman ini sangat tidak efektif atas tindakan yang di ambil oleh salah satu pendukung kandidat yang kalah karena masjid ini bukan saja milik kades terpilih tetapi adalah tempat masyrakat beribadah dan lagi salah satu pendukung kandidat yang kalah tersebut merupakan pegawai masjid 
jadi dengan tindakan yang di ambil nya kurang rasa tangung jawab terhadap tugas yang di embannya.

c. Beginilah pendapat salah satu informan bapak tohirin mengenai tidak mau sholat juamat di dalam satu masjid dengan kades terpilih dan lebih memilih sholat jumat masjid dusun lain. Tindakan yang di ambil oleh seorang pendukung kandidat yang kalah adalah ini tidak memikirkan rasa tangung jawab terhadap tugas yang di embannya dan lagi beliau adalah salah satu pengurus masjid seharusnya bisa memberikan contoh yang baik kepada masyarakat umumnya, karena seseorang yang sudah di tunjuk sebagai pengurus masjid itu tentu orang yang lebih paham dalam bidang agama dan di percaya bisa bertangung jawab terhadap tugasnya.

5. Tidak mau ikut yasinan

Kegiatan yasinan di desa air liki baru diadakan tiap malam jumat sama sekali tidak di ikuti oleh para pendukung kandidat yang kalah. Suatu Kegiatan yasinan yang merupakan kegiatan yang baik, menjaga silaturahmi dan berkirim doa ke sang pencipta menjadi kurang di repon oleh masyrakat terutama para kandidat yang kalah dan pendukungnya ,karena kegiatan ini di gerakann oleh kepala desa terpilih sehingga dengan perasaan emosi mereka setelah pilkades tahun 2016 kegiatan ini sengaja tidak mereka ikuti.

6. Dalam hal kerukunan masyarakat

Tidak terimanya kandidat yang kalah atas pilkadas pada tahun 2016 mengakibatkan adanya beberapa pihak pendukung kandidat yang kalah sengaja tidak megundang kepala dasa terpilih dalam segala hajatan yang mereka lakukan, seperti hajatan pernikahan, hajatan kiriman doa dan lain lain. Putusnya silaturahmi dan persaudaraan karena adanya ketidak sukaan atas kemenangan kades terpilih menjadi salah satu sebab kenapa pihak-pihak kandidat dan pendukung yang kalah samasekali tidak mengundang kades pada acara yang mereka adakan karena anggapan mereka yang menilai tidak usah lagi mampedulikan lagi kades terpilih dan aparatur pemerintahannya.

Konflik atau pertantangan politik, yaitu konflik yang terjadi adanya kepentingan atau tujuan politik seseorang atau kelompok.

a. Dugaan munculnya isu politik uang

isu sempat menggegerkan dan membuat situasi panas di desa air liki baru yaitu munculnya dugaan politik uang sehingga kandidat yang tidak terpilih dan masing- masing para pendukung tidak terima dengan kekalahannya, meskipun isu sekarang terbantahkan. Perkara politik uang adalah suatu upaya penghalanng untuk seseorag suapaya di batalakan menjadi kepala desa, tidak heran dalam hal ini isu politk uang yang muncul di desa air liki baru adalah sebuah wujud rasa kurang terimanya seseorang yang kalah menjadi kepala desa, karena mereka berharap nantinya masyarakat tidak suka dengan kepala desa terpilih dan situasi konflik akan terjai dan muli melebar.

b. Adanya nepotisme terhadap aparatur dasa

Adanya beberapa karabat saudara dan keluarga kepala desa terpilih yang duduk dan menjabat posisi pemerintaha yang ada sekarang menunjukkan adanya nepotisme terhadap pemerintahan yang ada.

Adanya nepotisme sebenarnya tidak masalah dalam pemerintahan yang ada asal sesual dengan skil dan kemampuan yang di miliki oleh para aparatur desa, tetapi masyarakat menilai tidak memberi kesempatan untuk manjabat manjadi aparatur pemerintahan dan menjadi sebab pandangan buruk masyarakat terhadap pemerintahan desa dan aparatur desa air liki baru yang ada.

c. Pelanggaran peraturan desa dalam hal ini peraturan desa di langgar yaitu seperti larangan meracun ikan 
Adanya keterlibatan beberapa pihak anggota pendukung yang kalah terhadap pelanggaran peraturan desa yang telah di sepakati menunjukkan adanya pertantangan dari pihak yang kalah kepada kades terpilih.

Pelanggaran peraturan desamerupakan salah satu bentuk konflik yang nyata pasca pilkades tahun 2016 apalagi ini orrang-orang yang terlibat salah satu pihak pendukung yang kalah tidak bisa menerima kekalahnnya maka iya melanggar peraturan desa yang sudah di tetapkan oleh kades terpilih bersama BPD

Dari beberapa bentuik konflik yang terjadi di desa di desa air liki baru dapat di lihat dengan jelas yaitu konflik yang terjadi di desa airliki baru yang didasari oleh konflik antar pribadi atau konflik antar individu-individu atau lebih karena perbedaan pandangan dan sebagainya, atas kekalahan kandidat yang kalah, kemudian tidak mau mengikuti kegiatan dan hilangnya rasa persaudaraan antar kandidat yang kalah kepada kandidat yang menang, selanjutnya konflin politik yaitu konflik yang terjadi adanya kepentingan ayau yujuan politis seseorang atau kelompok, dalam hal ini sangat jelas munculnya politik uang, nepotisme,dan pelanggaran perdes yang ada adalah salah satu bentuk pertantangan politik yang semua ini menjadi sebuah gambran bentuk-bentuk konflik pasca pilkades tahun 2016 di desa air liki baru.

Dampak Konflik Yang Terjadi Pasca Pilkades Desa Air Liki Baru

Dampak konflik yang terjadi pasca pilkades terhadap pembamgunan desa air liki baru karena dari adanya suatu konflik bisa meruntuhkan kerukunan dan kedamian masyarakat desa.

1. Dampak terhadap pembangunan

Dampak yang terjadi te pasca pilkades desa air liki baruTidak terimanya hasil kekalahan salah satu para kandidat dan pendukungnya yang kalah dan berdampak tidak baik terhadap pembangunan di desa air liki baru pada suatu pemmbangunan infrasruktur jalan desa yang mana tidak didukung oleh salah satu pendukung kandidat yang kalah dengan melarang membangun jalan di tanah mereka.dampak yang terjadi terhambatnya suatu pembangunan desa air liki baru dikarenakan tidak boleh membuka jalan atau memperbaiki jalan desa tentu bisa menjadi salah satu penghamabat kemajuan desa di tingakat pembangunan di karenakan kepala desa harus membuka jalan baru, tentu membutuhkan Dana yang banyak dan seharusnya tahap selanjurtnya bisa membangun ke pembangunan yang lain tetapi ini masih membangun jalan, jadi dengan konflik yang terjadi membuar terhambatnya suatu pembangunan dan kemajuan desa.

2. Dampak terhadap sosial budaya

Terbentuknya suatu kelompok pasca pilkades dapat mengakibatkan pudarnya kerukunan dan kenymanan masyarakat desa air liki baru karena sebelum pilkades tahun 2016 masyarakat terlihat biasa-biasa saja baik itu ditempat berkumpul atau dalam acara didesa dan pertandingan antara dusun sebelumnya masyarakat air liki baru sangat antusias dalam hal kerja sama seperti menyambut tamu-tamu besar yang datang dari luar misalnya bupati beserta rombongan tetapi pasca pilkades tahun 2016 sudah terbentuknya kelompok- kelompok antara masyarakat dari para kandidat yang kalah dan masyarakat dari pendukung kandidat kades terpilih maka pudarlah kerukunan dan kebersamaan masyarkat desa air liki baru.

\section{Bentuk penyelesaian konflik pasca pilkades desa air liki baru}

Upaya adalah usaha atau ihtiar untuk mencapai suatu maksud, memecahkan persoalan, mencari jalan keluar dan sebagainya. Sedangkan upaya penyelesean konflik adalah usahaaa manusia untuk merdakan atau konflik dalam mencapai kestabilan. 
Berdasarkan hasil pengamatan peneliti upaya kepala desa dalam menyelesaikan konflik antara lain yaitu:

1. Conciliation (konsiliasi)

Merupakan suatu usaha untu memrertemukan keinginan-keinginan dari pihak-pihak yang berselisihdemi tercapainya suatu persetujuan bersama.Dalam hal ini para tokoh masyarakat dan lembaga adat yang sudah melihat dan mengamati konflik yang terjadi pasca pilkades tahun 2016 berlangsung lama, berinisiatif mengajak para anggota BPD dan kepala desa terpilih untuk menyelesaikan permasalahan yang ada, dimana ia mengusulkan di adakan sebuah pertemuan antara bapak kades terpilih dan kandidat-kandidat yang kala biar nantinya terjadi titik temu atas permasalahan dan penyelesean konflik yang ada pasca pilkades tahun 2016 di desa air liki baru.

Upaya yang di lakukan BPD dan tokoh masyarakat untuk memenuhi pihak-pihak yang sedang berrkonflik adalah satu cara yang sangat bagus, dimana dalam hal ini kedamean dan hilangnya rasa kekeluargaan, persaudaraan, pertemanan akibat pertantangan atar kandidat yang kalah dan kades mulai berkurang dan kedamian segera terwujud. Berbagai konflik yang terjadi pasca pilkades di desa air liki baru tahun 2016 tidak lah melemahkan semangat dari kades terpilih untuk menyelesaikan konflik tersebut dengan berbagai cara walaupun ada beberapa hambatan dan rintangan niat kades terpilih ingin menyatukan kembali semua masyarakatnmya kerena pilkades sudah berakhir dan saat nya membangun desa dan demi kemajuan desa air liki baru.

2. Compromise (Kompromi)

Suatu cara dimana pihak-pihak yang terlibat saling mengurangi tuntutannya, agar tercapainya suatu terhadap perselisihan yang ada. Sikap dasar untuk dapat melaksanakan kompromi adalah bahwa salah satu pihak bersedia untuk merasakan dan memahami keadaan pihak lainnya. Kompromi memang upaya atau jalan yang dilalukan kepala desa dan para kandidat yang lain dalam menyelesaikan konflik pasca pilkades tahun 2016 desa air liki baru, dimana dalam hal ini para kandidat yang kalah mulai mengurangi tuntutannya tentang permasalahan kecurangan pilkades tahun 2016 karena masa berlaku gugatannya yang sudah berakhir. Selain itu kandidat tidak terpilih sekarang jugadiajak untuk ikut serta dalam setiap acara program atau kegiatan desa yang ada, misalnya dalam hal program pertanian yang dulu sempat terhambat tidak di terima oleh kandidat yang kalah, sekarang ketuanya sendiri adalah salah satu kandidat yang kalah yantu bapak iwan salah satu kandidat kades tidak terpilih, selanjutnya dalam hal lain juga terselesaikan dimana para pendukung kades tidak terpilih sudah mau ikut berpartisipasi dalam kegiatan desa air liki baru antara lain seperti gotong royong desa, yasinan dan lain-lain. Upaya kepala desa tepilih dalam penyelesian konflik pasca pilkades tahun 2016 di deasa air liki baru mengedepankan pendekataan individu dan kekeluargaan secara langsung oleh kepala desa kepada kandidat yang kalah dan pendukungnya. Melalui pendekatan individu dan kekeluargaan secara langsung kepada pihak-pihak yang kalah yang melalui pendekatan kekeluaragaa kebijakan ini sangaat efektif untuk mengatasi konflik yang terjadi karena kedes terpilih dengan pihak konflik masih mempunyai ikatan kekeluargaan atau biasa di sebut dengan ninik mamak rumah dari kades terpilih. 


\section{Penutup}

Berdasarkan beberapa analisis lapangan yang ada pada penelitian di lapangan serta hasil dari analisishasil wawancara kepada pihak kepala desa tokoh masyarakat, para kandidat yang kalah dan npara pendukungnya, menyatakan bahwa maksalah konflik yang terjadi pasca pilkades tahun 2016, lebih dikarenakan rasa kekecewaan dan belum bisa menerimanya para pihak kandidat dan para pendukung yang kalah, sehingga munculnya beberapa konflik yang terjsdi pasca pilkades di desa air liki baru. Bentuk konflik yang muncul pasca pilkades tahun 2016 di desa air liki baru adalah 1) Konflik atau pertantangan pribadi, yaitu konflik yang terjadi antara dua individu atau lebih karena perbedaan pandangan dan sebagainya. a. Tidak mau menerima program-program pembangunan dan sebagainya; b. Tidak mau gotong royong; c. Tidak mau ikut musrembangdes; d. Tidak ikut kegiatan keagamaan di desa. 2) Konflik atau pertantangan politik, yaitu konflik yang terjadi alkibat adanya kepentingan atau tujuan politik seseorang atau kelompok. a. Isu politik uang; b. Nepotisme aparatur desa; c. Pelanggaran peraturan desa. Sedangkan upaya kepala desa air liki baru dalam penyelesaian maksalah lebih kepada konsiliasi dimana para tokoh masyarakat, BPD, kepala desa terpilih sepakat membuat pertemuan dengan kandidat yang kalah untuk membahas perundingan dan kesepakatan penyelesaian konflik, selain itu jalan konpromi juga di lakukan di mana para kandidat yang kalah mengurangi beberapa tuntutan seperti masalah kecurangan pilkades dan masalah lain nya dan selain itu kandidat yang kalah diajak ikut serta dalam kegiatan pemerintahan desa yang ada.

Saran dari penulis adalah (1) Untuk kepala desa agar senantiasa menjaga keharmonisan, kerukunan, kesatuan dan ketentuan desa agar nantinya upaya penyelesaian konflik di desa air liki baru ini tetap terjaga dan semakin membaik kedepannya.(2)Untuk kandidat yang kalah dan para pendukungnya agar bisa lapang dadadan menerima kekalahan pilkades kedepannya tidak lagi memvbuat konflik. (3) Agar tokoh masyarakat, tokoh adat dan perangkat desa selalau mengingatkan kepada kepala desa dan para pesaingnya dulu pada pilkades tahun 2016 supaya selalu menjaga ketentraman dan keutuhan dan desa air liki baru.

\section{Referensi}

Agustino, L. (2014). Politik lokal \& otonomi daerah. Penerbit Alfabeta.

Dhuroriudin, I. gayatri. (2005). konflik elit politik perdesaan. pustaka belajar.

Fatoni, A. (2011). Metode penelitian penyusunan sriksi. rineka cipta.

Hikmawan, M. D. (2017). Pluralisme Demokrasi Politik di Indonesia. Journal of Governance, 2(2).

Hugh, M., Oliver, R., \& Tom, W. (2000). Resolusi damai Konflik kontemporer. Menyelesaian,

Mencegah, Mengelola, dan Mengubah Konflik Bersumber Konflik, PT RajaGrafindo Persada, Jakarta.

Nawawi, H., \& Hadari, M. M. (1992). Instrumen penelitian bidang sosial.

Nurcholis, H. (2011). Pertumbuhan \& penyelenggaraan pemerintahan desa. Erlangga.

Nurtjahjo, H. (2006). Filsafat demokrasi.

Rozali, A. (2005). Pelaksanaan Otonomi Luas Dengan Pemilihan Kepala Daerah Secara

Langsung. Rajawali Pers, Jakarta.

Singarimbun, M., \& Effendi, S. (1989). Metode Penelitian Survei, Jakarta. Kegiatan Wisata Bahari

di Resort Pengelolaan Wilayah Pulau Harapan Taman Nasional Kepulauan Seribu.

Sodikin. (2017). Upaya kades dalam menyelesaikan konflik internal.

Soetrino, L. (1998). Menuju masyrakat madani. aditama.

Surbakti, R. (1992). Memahami Ilmu Politik, Jakarta: PT. Gramedia Widiasarana Indonesia

Susan, N. (2010). Pengantar sosiologi konflik dan isu-isu konflik kontemporer. Jakarta: Kencana.

Syamsuadi, A., Zamhasari, Z., Hartati, S., \& Trisnawati, L. (2020). Pragmatisme Partai 
Islam: Strategi Politik Terbuka Partai Keadilan Sejahtera dalam Pemilihan Gubernur dan Wakil Gubernur Riau Tahun 2018. JISPO Jurnal Ilmu Sosial Dan Ilmu Politik, 10(1), 122. https://doi.org/10.15575/jispo.v10i1.8162

Ulber, S. (2012). Metode Penelitian Sosial, PT Refika Aditama.

Undang-undang Negara nomor 6 tahun 2014 tentang desa permendagri nomor 112 tahun 2004 tentang PILKADES

Peraturan pemerintah nomor 72 tahun 2014 tentang penyelengaraan urusan pemerintahan 